\title{
'Destitute of the knowledge of God': Māori Testimony Before the New Zealand Courts in the Early Crown Colony Period
}

\author{
Shaunnagh Dorsett
}

In 1843 the imperial parliament passed the Colonial Evidence Act. ${ }^{1}$ Its purpose was to allow colonial legislatures to pass acts or ordinances to allow their indigenous inhabitants to give unsworn testimony before the courts. Unsworn testimony was testimony given by those who were not able to take the oath. At common law the rule was that evidence could only be given on oath, rendering those devoid of religious belief incompetent to testify. In British colonies, therefore, this rule resulted in most of the indigenous inhabitants being unable to give evidence before English courts. This was particularly problematic in the Australian colonies. The imperial Act of 1843 was the outcome of various ineffectual attempts to allow for such evidence by way of local act or ordinance, particularly in New South Wales and, more latterly, Western Australia. While some attention has been paid to the politics and processes of law reform concerning unsworn testimony in empire, and the ways in which such reforms formed part of broader disputes about the shape of colonial governments, ${ }^{2}$ these discussions have almost entirely revolved around the Australian colonies. ${ }^{3} \mathrm{New}$ Zealand has received comparatively little attention. To the extent to which New Zealand has been considered, it has been in the context of the overall matrix of imperial reform and therefore much of the particular politics and processes of reform within New Zealand still await consideration. ${ }^{4}$ Although New Zealand promptly took advantage of the imperial legislation and passed a local Ordinance under its auspices, the history of the interaction between Māori and the courts, and their ability to testify before them, prior to the passing of that Ordinance diverges significantly from that of the Australian colonies. The particular history of New Zealand in respect of unsworn testimony illustrates

1 Colonial Evidence Act 6 Vic. c. 22 (1843) (Imp).

2 See in particular Damen Ward, 'Imperial Policy, Colonial Government and Indigenous Testimony in South Australia and New Zealand in the 1840s', in Law and Politics in British Colonial Thought: Transpositions of Empire, eds, Shaunnagh Dorsett and Ian Hunter (New York: Palgrave Mcmillan, 2010); Russell Smandych, "Contemplating The Testimony of "Others": James Stephen, The Colonial Office, and The Fate of Australian Aboriginal Evidence Acts, circa 1839-1849', Australian Journal of Legal History 8 (2004): 237.

3 See also Nancy Wright, 'The Problem of Aboriginal Evidence in Colonial New South Wales', in Law, History, Colonialism: The Reach of Empire, eds, Diane Kirkby and Catharine Coleborne (Manchester University Press, 2001), 140-55.

4 For New Zealand and imperial reform see Ward. 
the interplay of local micro-politics with imperial imperatives, as well as the ways in which the colonial office sought to accommodate the needs of specific colonies within the often constrictive bounds of imperial constitutional law.

\section{Local dictates and imperial imperatives: The Land Claims Ordinances}

Unlike other indigenous groups around the empire, prior to the passing of the imperial Act, Māori already had some limited ability to give unsworn testimony. In the 1840 New Zealand Land Claims Act (NSW) provision was made for unsworn testimony to be given by Māori. ${ }^{5}$ The New Zealand Land Claims bill was introduced into the New South Wales Legislative Council in May $1840 .{ }^{6}$ Its purpose was to institute a process for investigating lands acquired from Māori pre 1840 and the conditions under which those lands were acquired. The official position was that only titles derived from the Crown itself would be recognised, and a proclamation to this effect had been issued by Governor George Gipps, prior to the signing of the Treaty of Waitangi. A proclamation to similar effect was issued by (then) New Zealand Lieutenant Governor William Hobson in early $1840 .^{7}$ Prior to this time, however, significant land had changed hands, purchased directly from Māori by pākehā (non- Māori, in this period generally white settlers). Land acquisitions from Māori, therefore, were to be investigated and those which were 'founded on equitable principles, and not in extent or otherwise prejudicial to the present or prospective interests of Her Subjects in New Zealand' were to be allowed and confirmed. ${ }^{8}$ Such a process had no parallel in other Australasian colonies, where the possibility of indigenous ownership of land was not even acknowledged. In New Zealand, however, the land claims investigations were critical to settlement of the new colony.

The bill was modelled on the Claims to Land Act 1835 (NSW), under which a Court of Claims was established to investigate claims to grants essentially where the Crown had made multiple promises to grants and the documentary records

5 New Zealand Land Claims Act 4 Vic. No. 7 (1840) (New South Wales). New Zealand was a dependency of New South Wales for 18 months between late 1839 and 1841. During this period the New South Wales Governor, Sir George Gipps, and the Legislative Council passed laws for New Zealand.

6 Votes and Proceedings of the Legislative Council 1840 No. 1, copy in Gipps to Russell, Despatch No. 40/66, 29 May 1840, The National Archives (TNA), CO 201/297, fol 190a/b. For a full account see The New Zealand Land Claims Act of 1840, Evidence of Dr Donald M. Loverage for the Crown, WAI 45 \#I 6 (Muriwhenua Claim), 1993 [revised version 2002] (Waitangi Tribunal, Wellington).

7 On 30 January 1840 Hobson read two proclamations, the first declaring the boundaries of New South Wales to include New Zealand; the second stating the Crown's intention to only recognise titles derived from the Crown itself: Issued 30 January 1840, Hobson to Gipps, TNA, CO 209/7, fol. 23-24.

8 Votes and Proceedings of the Legislative Council 1840 No. 1, 29 May 1840, TNA, CO 201/297, fol. 190a/b. 
were insufficient to establish the entitled grantee. ${ }^{9}$ Under both land claims acts, determinations were to be guided by 'real justice and good conscience'. Of course, the stark difference between the New South Wales and New Zealand acts was the New South Wales Act did not mention, or allow for the possibility of, indigenous owners. Nevertheless, it provided a convenient template that, in form, complied with Normanby's instructions to Gipps for the preparation of the Act. ${ }^{10}$ Section VII of the New Zealand Land Claims Act, generally dealing with the calling of witnesses, recording of evidence, and penalties for perjury, was derived from s 6 of the 1835 New South Wales Act. However, cl. VII included provisions for the evidence of 'Aboriginal Natives', a provision obviously absent in the original Act. The evidence of the Māori vendors was critical to the functioning of the Act. As in any investigation to title, it was necessary to receive the evidence of the seller as to the nature of the transaction.

At this time, unsworn testimony was still not permitted in any courts either in England or around empire. ${ }^{11}$ As noted above, unsworn testimony was testimony given by those who were not able to take the oath. At common law the rule was that evidence could only be given on oath, rendering those devoid of religious belief incompetent to testify. However, it had been accepted since the decision in Omichund $v$ Barker that the oath could be taken by 'infidels' who believed in a god and that they would be punished if they swore falsely. Chief Justice Sir Edward Willes noted that while the common law is a Christian institution, the substance of an oath predates Christianity, and has 'nothing to do with Christianity, only that by the Christian religion we are put still under greater obligations not to be guilty of perjury .... ${ }^{12}$ While the forms of oaths may vary, the substance is the same: God in all of them is called upon as a witness to truth. ${ }^{13}$ Thus, it followed that 'a man is not to be questioned as to his particular opinions, (as, whether he believes the gospels,) but, whether he believes in the

9 An Act for Appointing and Empowering Commissioners to Examine and Report upon Claims to Land under the Great Seal of the Colony of New South Wales, 5 Wm IV No. 21 (1835) (New South Wales), in turn based on an earlier Act of the same name: 4 Wm IV No. 9 (1833) (New South Wales).

10 Loverage, New Zealand Land Claims Act, 43.

11 A possible exception to this was the resolution of the Council of Assiniboa on 2 February 1837 allowing for the admittance of native testimony in all courts in the District of Assiniboa: 'Several Objections Having Been Made By Many Of The Colonists To The Validity Of Indian Evidence; It Is Resolved 1st. That The Evidence Of An Indian Be Considered Valid, And Be Admitted As Such In All Courts Of The Settlement'. The resolution is reproduced in E.H. Oliver, The Canadian North-West: Its Early Development and Legislative Records (Ottawa: Government Printing Bureau, 1914), vol. 1, 278. The resolution was of doubtful legal validity as it was likely repugnant to the common law. The earliest legislative endeavour to provide for such evidence was the 1764 draft legislation prepared by the British Parliament to supplement the Royal Proclamation of 1763. It was intended to establish a system of superintendents within the territory reserved for Indian Nations. The legislation specifically provided for both the appointment of superintendents and interpreters, as well as the taking of evidence in both civil and criminal matters from Indians (presumably non-Christian Indians): E.B. O'Callaghan, ed., Documents Relative to the Colonial History of the State of New York, vol. VII (Albany, New York: Weed, Parsons \& Co., 1856-61), 637. My thanks to Mark Walters for drawing this to my attention.

12 Omichund v Barker (1744) Willes 538, 547 (125 ER 1310, 1314).

13 ibid. 
existence of a God, and a future state'.$^{14}$ The rule was developed in the context of India. Thus, it was designed to allow evidence from those who believed in a god, but were not Christians. 'Infidel' testimony was admitted in a number of trials at the Old Bailey, although never the testimony of atheists. For example, in 1765, John Morgan, prosecutor in an action for theft, and a 'Mohametan', was allowed to swear on the 'Alcoran' at the Old Bailey. According to Morgan, 'I touch the book, the Alcoran, with one hand, and put the other to my forehead; then I look upon it I am bound to speak the truth' ${ }^{15}$ In $R v$ Sayhead, the prosecutor, Bonhalel, both a foreigner and a Mohametan, was able to give evidence through an interpreter, ${ }^{16}$ while in $R v$ Boxo Colloso, Boxo Tindle, Carder, a Mohametan originally from Bombay, swore on the 'forms of that religion', also giving evidence through an interpreter. ${ }^{17}$ However, problematically, most indigenous peoples, particularly in the Australian colonies, did not adhere to any recognisable religion. They were entirely 'destitute of the knowledge of God' and therefore unable to swear any oath, even under the common law 'infidel' exception.

While the practical purpose of admitting unsworn testimony before the Land Claims Commission was clear, the legal validity of the measure was unclear. The New Zealand Land Claims Act was passed by the New South Wales Legislative Council at a time in which Gipps's policy was to make general provision for the admitting of unsworn testimony by Aborigines. In October 1839 the New South Wales Legislative Council passed an Act to allow unsworn testimony. ${ }^{18}$ According to the despatch which accompanied the Act to London, the 'measure was introduced at the desire of the attorney-general in consequence of the difficulty of obtaining convictions which he experienced in several cases, wherein native blacks have been concerned, either as the accused or the injured party' ${ }^{19}$ The Act provided that evidence would be given 'so much weight as corroborating circumstances may entitle it to'. Further, it required evidence be corroborated by European witnesses. The Act, however, was disallowed. ${ }^{20}$ Gipps, it seems, had overreached himself. According to the barristers, Campbell and Wilde, to whom it had been referred for a legal opinion:

14 Samuel March Phillips, A Treatise on the Law of Evidence (London: Butterworth and Son, 1814), 11. To the same effect see Sir Geoffrey Gilbert, The Law of Evidence, sixth edition, vol. 1 (London: James Sedgwick, 1801), 129; Thomas Peake, A Compendium of the Law of Evidence, fourth edition (London: Reed and Hunter, 1813), 154-57.

$15 R v$ John Ryan, Jeremiah Ryan, Mary Ryan, 27 February 1765, Proceedings of the Old Bailey (http://www. oldbaileyonline.org), ref. no. t17650227-5 (theft) (Morgan's Case 1 Leach 53 (168 ER 129).

$16 R v$ Sayhead, 12 April 1809, ibid., ref. no. t8090412-57 (theft).

$17 R v$ Boxo Colloso, Boxo Tindle, 3 July 1822, ibid., ref. no. t8220703-20 (violent robbery).

18 An Act to Allow the Aboriginal Natives of New South Wales to be Received as Competent Witnesses in Criminal Cases 3 (Aboriginal Evidence Act) Vic. No. 16 (1839).

19 Gipps to Normanby, 14 October 1839, Historical Records of Australia: Series I, Governors' Despatches to and from England (Sydney: Committee of the Commonwealth Parliament, 1914-25), series I, vol. 20, 368 (HRA).

20 On this further, see Smandych. 
[t]o admit in a Criminal proceeding the evidence of a witness acknowledged to be ignorant of the existence of a God or a future state would be contrary to the principles of British Jurisprudence; and the Act is loosely worded with respect to the admission of which evidence and the weight to be given to it that we do not think it could be attended with any advantage. ${ }^{21}$

Between the time that the New South Wales Aboriginal Evidence Act was sent to London, and notification of its disallowance received in New South Wales, over a year had elapsed. During this time, the New South Wales Legislative Council had passed the New Zealand Land Claims Act. The unsworn evidence provision in this Act was broader than that in the soon to be disallowed Aboriginal Evidence Act. Section VII asserted that:

Provided always, that in all cases in which it may be necessary to take the evidence of any Aboriginal Native who shall not be competent to take an Oath, it shall be lawful for the said Commissioners to receive in evidence the statement of such Aboriginal Native, subject to such credit as it may be entitled to, from corroborating or other circumstances.

The New Zealand Land Claims Act was disallowed, although not for reasons relating to the unsworn testimony provision. Section VII was not mentioned, either in correspondence, or by James Stephen in his minute on the Act. Rather, attention was directed to the issue of the effect of the separation of New Zealand from New South Wales on the Ordinance. Russell was set on disallowance. ${ }^{22}$ He advised Hobson that the separation of New Zealand rendered 'obsolete and impracticable' generally arrangements 'which require the interposition of the governor of the old colony'. ${ }^{23}$ The characterisation of the Act as 'obsolete and impracticable' was that of James Stephen, who advised that laws passed by one colony could still operate in another - Quebec laws in the Canadas for example - unless they became obsolete and impracticable. Stephen may have left matters as they were but, given Russell's determination to disallow the Act, he advised that disallowance could be achieved simply by despatch. ${ }^{24}$ As a result, at the first session of the New Zealand Legislative Council, the New South Wales Act was replaced by the local Land Claims Ordinance (NZ). ${ }^{25}$ Section 9,

21 The attorney-general and solicitor-general to Russell, 27 July 1840, HRA, series I, vol. 20, 756.

22 Russell, Minute, appended to Gipps to Russell, 16 August 1840, TNA, CO209/6, fol. 420.

23 Russell to Hobson, 16 April 1841, Despatch No 41/27 of 16 April 1841, British Parliamentary Papers (BPP) 1841 XVII (311), 60 and Russell to Gipps, 16 April 1841, BPP 1841 (311), 60. Both Hobson and Gipps were instructed to postpone notification of the disallowance of the Act, pending passing a new Ordinance.

24 Stephen, Minute, appended to Gipps to Russell, 16 August 1840, TNA, CO209/6, fol. 420.

25 Land Claims Ordinance 4 Vic. No. 2 (1841). 
providing for unsworn evidence, was identical to s. 7 of the original Act. This Ordinance was allowed. ${ }^{26}$ Again, the unsworn testimony provision received no obvious attention, either locally or at the Colonial Office.

Perhaps, as Gibbs was so certain that the original unsworn evidence Ordinance would be approved, he did not allude to this unusual provision. Neither did Hobson, who presumably had neither any idea of its unusual nature nor that the Aboriginal Evidence Ordinance had been disallowed. In neither Gipps's instructions to the commissioners on their appointment, nor Hobson's (substantially similar) instructions on their reappointment under the new Ordinance, was the matter of Māori evidence mentioned..$^{27}$ In both sets of instructions Edward Godfrey and Mathew Richmond were simply reminded that in summoning witnesses and recording evidence they were to be guided by the Act. Both sets of instructions, however, made it clear that a protector must be present at all proceedings, as must a competent interpreter. The protector could function as both. ${ }^{28}$

After the 1841 Land Claims Ordinance had been allowed, the law officers, Pollock and Pollett, recommended disallowance of the Western Australia Aboriginal Evidence Act (1841). ${ }^{29}$ This Act had been passed in part on the urging of Russell, following the disallowance of an earlier Ordinance. ${ }^{30}$ On 26 October 1842, some eight months after the New Zealand Land Claims Ordinance was allowed, they reported that the 1841 Western Australian Act suffered from the same defect as the earlier New South Wales Act. It was repugnant. They stated that: 'the two Acts are in fact, as far as regards the nature of these objections, substantially the same' ${ }^{31}$ This led Stephen to suggest the enactment of an imperial statute. It was obvious that the local legislatures did not have the constitutional power to override a principle that was, at least as far as the law officers were concerned, fundamental to the common law. ${ }^{32}$

\footnotetext{
26 Lord Stanley to Governor Hobson, Despatch No. 27/42, 18 March 1842, BPP XXVIII (569), 464.

27 Gipps to Commissioners, 2 October 1840, TNA, CO209/6, fol 407ff; Hobson to Godfrey and Richmond, Instructions for the Commissioners, Archives New Zealand (ANZ), OLC 5/4B, 4.

28 On the other hand, the final commissioner, Spain, appointed from London, received no specific instructions. William Swainson and Chief Justice William Martin (prior to their departure to New Zealand), suggested that it would be desirable to furnish Spain with a full set of instructions: Martin to Russell, 10 March 1841, TNA, CO209/13, fol. 185. James Stephen responded to Russell that, as there was a 'positive law prescribing his duties', his instructions would simply be to execute the Act. No further instructions were required: Stephen, Minute, 12 March 1841, TNA, CO 209/13, fol. 367.

29 An Act to Allow the Aboriginal Natives of Western Australia to give Information and Evidence without the Sanction of an Oath 4 \& 5 Vic. No. 22 (1841). See generally Ann Hunter, 'The Origin and Debate Surrounding the Development of Aboriginal Evidence Acts in Western Australia in the Early 1840s', University of Notre Dame Australia Law Review 9 (2007): 115.

30 An Act to allow the Aboriginal Natives of Western Australia to give Information and Evidence in Criminal Cases and to enable Magistrates to award Summary Punishment, for certain Offences (1840) 4 Vic. No. 8. The terms of this Act were quite different to its New South Wales counterpart. For the reasons for the disallowance of this earlier Ordinance see generally Hunter, ibid.

31 Pollock and Pollett (Law Officers) to Stanley, 26 October 1842, TNA, CO 201/337, fol. 295, in Smandych, 270. 
So, why was no comment made on the unsworn testimony provisions of either the original New South Wales New Zealand Land Claims Act 1840 or the 1841 New Zealand Land Claims Ordinance? The New Zealand provisions were, after all, broader than those of either the New South Wales or Western Australian acts, which had been disallowed. The acts were scrutinised by James Stephen and it is impossible that he simply failed to notice the unsworn testimony provision. In 1813 Stephen, still a young lawyer, was appointed by the Colonial Office to scrutinise colonial laws on a fee basis. ${ }^{33} \mathrm{He}$ was paid three guineas per Act. In 1825 he was appointed as legal advisor to the Colonial Office and counsel to the Board of Trade, where he continued to scrutinise and comment on colonial legislation and, in 1836, he became permanent under-secretary. In this role he continued his previous task of reporting on colonial acts and ordinances. After 1813, on the advice of Stephen, it became required that all colonial laws were sent to London. It was in any case a requirement in most governors' standing orders that they do so. Failure to do so could, and did, lead to them being declared invalid. ${ }^{34}$ Most acts and ordinances were reported on by the Colonial Office legal adviser (namely Stephen). Where the colonial law was potentially repugnant, however, the solicitor-general or attorney-general might, on advice from the Colonial Office, appoint Crown law officers to write an opinion. ${ }^{35}$ This latter process had, of course, occurred in the case of both the New South Wales and the Western Australian Aboriginal Evidence acts. Stephen, most likely at the direction of the secretary of state for the colonies, The Hon Edward Stanley, referred the Western Australian Act to the law officers, aware of the advice that would come back. There seems little doubt, however, that as a matter of policy Stephen, as well as both Russell and Stanley, was in favour of allowing unsworn testimony. Stephen's recommendation to disallow the Western Australian Act was reluctant, and conveyed only because it seemed impossible not to make such a recommendation in light of the law officer's opinion that the Act was repugnant. ${ }^{36}$

What then constituted repugnancy? And in what circumstances and on what grounds were colonial ordinances and acts disallowed? Most problematic was where an act or ordinance was supposedly repugnant to the common law. The unsworn testimony provisions were enacted at a time of transition in the conventional meaning of 'repugnancy' and the way in which it was interpreted. In 1851, Rogers, Stephen's successor, noted that the unsworn testimony ordinances of the early 1840s had been one of the most obvious examples of the problems

\footnotetext{
33 Paul Knaplund, James Stephen and the British Colonial System 1813-1847 (Madison: University of Wisconsin Press, 1953), 12.

34 ibid., 38-39.

35 D.B. Swinfen, Imperial Control of Colonial Legislation, 1813-1865: A Study of British Policy towards Colonial Legislative Powers (Oxford: Clarendon Press, 1970).

36 Stephen, Minute, 28 February 1842.
} 
of determining the meaning of repugnancy to the common law. ${ }^{37}$ Smandych records that Stephen was privately of the opinion that neither the New South Wales Act nor the Western Australian Act were repugnant as they were not, in his opinion, contrary to the 'principles of British Jurisprudence'. Indeed, admitting such evidence was neither opposed to divine law or to Englishmen's Birthright. ${ }^{38}$ By contrast, the law officers took a narrower approach, whereby a statute was repugnant if it was in contravention of a rule of the common law, such as that of the requirement of taking the oath. For Stephen, no fundamental common law principle was at stake in the matter of unsworn evidence. To the contrary, to allow such evidence would have been in the best interests of justice. ${ }^{39}$ By the late 1840s, Stephen's position was the accepted one and, by the time of the Colonial Laws Validity Act, the position had been reached that colonial legislatures could pass any law unless it directly contradicted with an imperial statute intended to apply to that colony. ${ }^{40}$ Of course, this explanation assumes that repugnancy was always and only a question of law. As significant as the legal position, however, was the politics of disallowance, of which the Aboriginal Evidence acts are a key example. ${ }^{41}$

As a matter of speculation, there are two possible, not necessarily mutually exclusive, explanations for the failure to disallow the unsworn testimony provisions in the Land Claims Act and Land Claims Ordinance. The first is that Stephen simply determined as a matter of pragmatism that the matter should go ahead, aware of the result of referring the Ordinance to the law officers. Despite their opinions of both the New South Wales and Western Australian acts, Stephen was not of the opinion that unsworn testimony provisions were actually repugnant. Was then the provision simply ignored? While this is a simple explanation, problematically the Land Claims Ordinance was in fact referred to the law officers, who simply noted that they 'had no objection in point of law'. ${ }^{42}$

The second possible explanation lies in the nature of the Land Claims Commission itself. ${ }^{43}$ The Land Claims Commission was to be guided by 'real justice and good conscience'. Consequently, the commissioners were to act 'without regard to legal forms and solemnities'. ${ }^{44}$ The commission, therefore, was a species of

\footnotetext{
37 Swinfen, 61.

38 Stephen, Minute, 28 February 1842. An example of a fundamental common law principle might be found in the Picton incident, in which Governor Thomas Picton of Trinidad was brought to trial in 1806, charged with inflicting torture in order to extort the confession of Louisa Calderon, a British subject.

39 Minute, Stephen, ibid.

40 Swinfen, 65.

41 On repugnancy in all its guises see Damen Ward, 'Legislation, Repugnancy and the Disallowance of Colonial Laws: The Legal Structure of Empire and Lloyd's Case (1844)', Victoria University of Wellington Law Review 41 (2010): 381.

42 Pollock and Pollett (Law Officers) to G.W. Hope, 12 March 1842, TNA, CO 209/17, fol. 172.

43 My thanks to Damen Ward for suggesting this line of argument.

44 Land Claims Ordinance 1841, s. 6.
} 
statutory court of 'equity and good conscience'. Thus, it was neither a court of common law nor equity, ${ }^{45}$ and decisions were to be made according to the more discretionary norms of 'real justice and good conscience', although such courts could apply common law or equitable principles, or a modified version of them. The first courts of 'equity and good conscience' were small debt courts, ${ }^{46}$ later more generally courts of request. ${ }^{47}$ In England, such courts were designed to allow matters to be determined in a manner that was shorn of the need for technicalities, difficult pleading or even lawyers, and they were often run by laypersons. The Land Claims Ordinance further directed that the commissioners were to direct themselves by 'the best evidence they can procure, whether the same be such evidence as the law would require in such cases or not' ${ }^{48}$ Otherwise, the commissioners had similar powers to call witnesses and require documents to be produced as the Supreme Court. ${ }^{49}$ Evidence, other than Māori evidence, was by oath. There is, however, no suggestion that the particular issue of Māori evidence in any way dictated the court's form. As noted above, that form was conveniently based on the 1835 New South Wales Land Claims $A c t$, the form of which in turn had been suggested by the judges of the Supreme Court of New South Wales, based on (unspecified) 'American precedent' ${ }^{50}$ It may be, therefore, that it was considered by the Colonial Office that, as the land commission was not a common law court, its provisions could not be repugnant to the common law. Further, although not specified by the Ordinance, no appeal would be possible to the Supreme Court. This would include appeals on matters of competency (of either pākehā or Māori witnesses).${ }^{51}$ As a statutory jurisdiction, unique rules could be set as to who gave evidence, and under what circumstances. However, had this been the case, it is unclear whether the Ordinance would have been referred to the law officers for an opinion in the first place.

Importantly, the land claims process, one which was of profound significance to the colonisation of New Zealand (and one, given the agitations of the New Zealand Company, of profound political import - both in England and locally),

45 Courts of equity and conscience were neither courts of common law or of equity: Becke $v$ Wells $1 \mathrm{C} \& \mathrm{M}$ 76 (1832) (149 ER 321).

46 The first appears to have been An Acte for the Recovering of Small Debt, and for relieving of the poore Debtors in London 3 Jac I, c. 15 (1605).

47 On courts of request as courts of equity and conscience see Harry Arthurs, Without the Law: Administrative Justice and Legal Pluralism in Nineteenth-Century England (University of Toronto Press, 1985).

48 Land Claims Ordinance 1841, s. 6.

49 ibid., ss. 7, 10.

50 The Act was established on the advice of the Forbes Supreme Court. Sir Francis Forbes CJ, Sir James Dowling and William Westerbrook Burton JJ suggested that a court of equity and good conscience be established: Judges to Colonial Secretary, 18 May 1833, Chief Justice's Letter Book, 1824-1835, State Records of New South Wales, 4/6651, 331.

51 The Ordinance is silent as to appeals. However, the general rule was that no appeal lay to a common law court by writ of error or writ of false judgment from a court of equity and good conscience: Scott $v$ Bye 2 Bing 344 (1824) (130 ER 338). Further, there is no record of any appeal ever having been made on any grounds. 
could not have proceeded without such a provision. ${ }^{52}$ In the end, imperial dictates and local need may simply have overridden strict legal requirements. The specific requirements of the colonisation of New Zealand could not perhaps be deferred to British imperial law. The answer may be all of the above, and may never be known.

\section{Māori, the courts and the local ordering of law}

While Māori were giving evidence before the specialist Land Claims Court, they were also giving evidence before the regular courts. In this case, however, it was not as a result of special statutory authority, but because the high level of Christianisation meant that, prior to the passing of the Unsworn Testimony Ordinance, many Māori were already able to give evidence before the regular courts, either swearing as Christians, or under the 'pagan' or 'infidel' rules. Just as the sale of land (and therefore the involvement of Māori in the process) was critical to the legal settlement of the colony, the participation of Māori in the regular courts was also crucial to that settlement, here through their participation in the establishment of the domestic legal order. Māori appeared in legal proceedings before all levels of court: magistrates courts; coroner's court; County Court; and the Supreme Court itself. They also appeared in criminal proceedings and those concerning commerce. Their high level of integration into the local fabric of law distinguished New Zealand from the other Australasian colonies. While in New South Wales, for example, Indigenous Australians were subjected to law (as defendants or victims), Māori were active participants in the legal process, not only subject to, but witnesses in, and initiators of, legal proceedings. ${ }^{53}$ This level of engagement with law is undoubtedly one of the reasons why the passing of the Ordinance in 1844 was so uncontroversial. The high conversion rate of Māori to Christianity was a feature of the colony. Māori often described themselves in court as 'missionaries', or 'Mihinare', showing that they were Christian (and probably Anglican in particular). The editor of the New Zealand Gazette referred to those able to take the oath as missionaries: 'if any of the witnesses for the prosecution are not "Missionaries", the best way would

\footnotetext{
52 In practice, the commissioners would not proceed without the evidence of the Māori vendors. James Busby, the former British resident to New Zealand, had two claims rejected because of his refusal to call the relevant vendors as witnesses, although he did call other witnesses, mainly pākehā, but also one Māori, who had been present at the signing of the deeds of purchase. The result of this rejection was that the governor refused to allow him to re-file or proceed with these claims.

53 For an example of an action initiated by Māori see the prosecution of Steele for assault by a Māori woman, Caroline: Caroline v Steele, 8 September 1843, Police Magistrates Court, Auckland, reported in Auckland Chronicle, 13 September 1843, 2; or a civil action in the Supreme Court in contract for the value of 193 pigs: Ropata Nuitone o Te Pakaru v Johnsone Wilkinson, 7 September 1846, Supreme Court, Auckland, Martin CJ, Auckland civil minute book, 1844-56, ANZ, Auckland, BBAE 5635/1a, 47 reported in New Zealand Spectator and Cook's Strait Guardian, 26 September 1846, 4.
} 
be to instruct them now in the sanctity of an oath and the existence of a Deity' ${ }^{54}$ Măori converted to Christianity in large numbers from the 1820s and, by the Crown Colony period, Christianity had spread to almost every iwi (tribe). There are differing explanations for this extent of conversion, all of which may have played a part. ${ }^{55}$ Suggestions include a fatal impact to existing belief structures that was experienced from encountering European culture; that disadvantaged groups gained influence from the new religion; that missionaries were a source of mana (prestige); that Māori adapted by creating a Māori Christianity; and that they desired to learn the 'magic of writing' ${ }^{56}$ Religion was integrated into a worldview that was built around structured rules which fused physical and spiritual domains. As Raeburn Lange tells us, religious authority was integrated into the existing structure of local leadership as it was 'consistent with Māori understandings of power' ${ }^{57}$

As a result, many Māori could give sworn testimony before both the county court and the Supreme Court, although it appears they were as frequently sworn under the 'pagan' or 'infidel' rules. At the first session of the Supreme Court in Wellington, held by Henry Samuel Chapman, first puisne judge of the Supreme Court, the grand jury was asked to find a true bill against John McCarthy for stealing some clothes which were the property of 'an aboriginal native'.$^{58}$ The only witnesses to the alleged crime were Māori. Chapman informed the grand jury of the circumstances in which 'pagan' (or 'infidel') witnesses could give evidence. When the witnesses came to be sworn, they were asked whether they were Christians. Two confirmed that they were, and were sworn. The others are reported to have 'answered with a shrug of the shoulders "au" [sic]. ${ }^{59}$ However, Chapman declined to further question the beliefs of these potential witnesses, rather he asked the crown prosecutor if the trial could proceed without them, and it did. A true bill was presented and McCarthy was tried. He was convicted on the evidence of the two sworn Māori witnesses, Pukahu and Tokoiwa. In McCarthy, although in the end only taking sworn evidence,

54 New Zealand Gazette and Wellington Spectator, 26 July 1843, 3.

55 Lachy Paterson, 'Maori Conversion to the Rule of Law and Nineteenth-Century Imperial Loyalties', Journal of Religious History 32 (2008): 216, 220.

56 For a summary of these, from which this is taken, see Paterson, ibid.; see also Raeburn Lange, 'Indigenous Agents of Religious Change in New Zealand 1830-1860', The Journal of Religious History 24 (2002): 279; Gary Glover “"Going Mihinare”, “Experimental Religion” and Maori Embracing of Christianity - A Reassessment', Christian Brethren Research Fellowship Journal 121 (1990): 44.

57 Lange, ibid., 288.

58 New Zealand Gazette and Wellington Spectator, 1 May 1844, 3, reporting on the Supreme Court session of 12 April 1844. Chapman arrived in Wellington in February 1844. Prior to this time there had been no permanent Supreme Court in Wellington. Martin CJ, on circuit, held the first Wellington session of the Supreme Court on 4 October 1842.

$59 R v$ McCarthy, Supreme Court, Wellington, Chapman J, 17 April 1844, reported in the New Zealand Gazette and Wellington Spectator, 1 May 1844, 3; [HS Chapman], Notebook entitled 'Criminal trials No.1', 1844-45, MS-0411/009, Hocken Library, Dunedin, entry for 17 April 1844, 15-18. Rather than 'au' (meaning I), the witnesses presumably shrugged and said 'aua' — meaning I don't know, or no. 
Chapman J nevertheless instructed the court generally on the rules of unsworn evidence so as to 'satisfy your minds on a point on which I know considerable misconception prevails'. According to Chapman:

a pagan witness who believes in a supreme being, who will punish him for telling a lie, either in the next world or in this, is a good witness, provided he be sworn according to the ceremonial which he believes to be binding on his conscience. ${ }^{60}$

Further, according to Chapman, the fact that the imperial parliament had just passed a law to admit pagan witnesses without oath was 'proof that they could not now be admitted' ${ }^{61}$

Prior to the 1844 Ordinance there are only three instances, other than McCarthy, of Māori giving evidence before the Supreme Court, all tried before Martin CJ: $R v$ Maketu; $R v$ Leethart; and $E$ Poti. ${ }^{62}$ Most of the interaction between Māori and the courts occurred at the lower level county courts, or even before magistrates. In Maketu, decided at the first sitting of the new Supreme Court, three Māori witnesses were called: Tohu, E Atohu and E Hoa. All three were examined by sworn interpreter, George Clarke Jr, who was later appointed subprotector for Wellington. According to the newspaper report, Tohu, (commonly called Charley Penny) was asked if he was a Christian, to which he replied no. He was further asked if there was a God, to which he replied that he believed there was a God, and 'if he spoke falsely he would be punished'. He was sworn, 'but did not kiss the book'. ${ }^{63}$ The latter two witnesses were also examined, but no comment is made as to how they were sworn. Leethart was tried at the same session. Leethart, annoyed at alleged trespass, deliberately shot at Pooterai. ${ }^{64}$ He was tried for 'shooting to cause grievous bodily harm', and convicted of

60 McCarthy, ibid.

61 McCarthy, ibid. Chapman was generally in agreement with the need to reform these rules of evidence, and would have preferred non-Christian evidence to be by affirmation (ibid). He was not in favour of 'pagan oaths'. Most particularly, he was not in favour of non-Christian forms of swearing. In extra-judicial commentary he had previously condemned such practices, specifically including the practice by which 'Chinese' swore on cracked saucers or, in the West Indies, witnesses 'swore on the dirt of graves': H.S. Chapman, 'Legal Notes', c. 1858, Alexander Turnbull Library, Wellington (ATL) MS Papers-8670-047. The paper is undated. It is part of a collection of materials, including correspondence, which has been collated and designated c. 1858 by the ATL. However, the internal evidence points to this document having been written around 1845. On this, and Chapman's views on 'barbarous customs' generally see Shaunnagh Dorsett, "'Sworn on the Dirt of Graves": Sovereignty, Jurisdiction and the Judicial Abrogation of Barbarous Customs in New Zealand in the 1840s', The Journal of Legal History 30 (2009): 175.

$62 R v$ Maketu, Supreme Court, Auckland, Martin CJ, 2 March 1842, reported in New Zealand Herald and Auckland Gazette, 5 March 1842, 2; R v Leethart, Supreme Court, Auckland, Martin CJ, 2 March 1842, reported in New Zealand Herald and Auckland Gazette, 5 March 1842; $R v$ E Poti, Supreme Court Wellington, Martin CJ, 7 Oct. 1842, reported in New Zealand Gazette and Wellington Spectator, 19 October, 1842, 3.

$63 R v$ Maketu, Supreme Court, Auckland, Martin CJ, 2 March 1842, reported in New Zealand Herald and Auckland Gazette, 5 March 1842, 2.

64 William Swainson, New Zealand and its Colonisation (London: Smith, Elder and Co., 1859), 58. Swainson was attorney-general at the time. 
common assault. Of the three witnesses one, Tooke, was Māori. He was similarly asked if he was a Christian, and replied that he believed if he spoke falsely he would be punished. ${ }^{65}$

In E Poti, it was reported that a Māori, having been placed in the witness box, had the usual oath administered to him. Mr Clarke (the same George Clarke Jnr who had interpreted in Leethart and Maketu) translated the oath for him. Then, 'the Maori took the puka puka [book] and swore'. However, the report goes on to say that the swearing took place 'in a manner indicative of an entire unacquaintance with the real nature of an oath' ${ }^{66}$ In fact, the editor was entirely outraged by the trial, stating that:

Not only was the prisoner a Moari [sic], but also the aggrieved person, and consequently the whole case constituted one of those acts, which might fairly have been tried by native laws and customs. Neither the accuser nor the accused knew a word of our language. An interpreter was required to translate the indictment to the prisoner, and to interpret the awfully responsible oath which an accuser takes in all cases of a criminal nature. ${ }^{67}$

Despite the brevity of the above descriptions, they are the best that can be discerned from the historical record. No case, for example, was appealed from a lower court to the Supreme Court on the grounds of inadmissibility of evidence. There are other instances of Māori giving evidence, before the Magistrates, the Court of Quarter Sessions and the County Court. ${ }^{68}$ In these instances, the detail is missing. We might assume, therefore, that all Māori were sworn under the same common law rules as in the decisions of the Supreme Court. However, there is some evidence that this was not so. During the session at which McCarthy was tried, Chapman asked the Crown Prosecutor what the practice was concerning unsworn Māori testimony. The prosecutor replied that the practice in the County Court had been to allow evidence to be taken without oath and leave the weight to be given to it to the jury. ${ }^{69}$ Presumably he could only speak for practice in the

$65 R v$ Leethart, 2 March 1842, Supreme Court, Auckland, Martin CJ, reported in New Zealand Herald and Auckland Gazette, 5 March 1842, 2.

$66 R v E$ Poti, Supreme Court Wellington, Martin CJ, 7 October 1842, reported in New Zealand Gazette and Wellington Spectator, 19 October 1842, 3.

67 Editorial, New Zealand Gazette and Wellington Spectator, 19 October 1842, 2. Interpreters had been provided at the trial. The role of interpreters has not yet been the subject of sustained inquiry. For example, what effect, if any, did the way in which interpreters asked questions as to religious belief impact on determinations as to the admissibility of testimony?

68 The County Court was created by 5 Vic. No. 2 (Ordinance passed 29 Dec 1841 and taking effect 1 March 1842). The same Ordinance abolished the Courts of General and Quarter Sessions. The court had criminal jurisdiction in all crimes except perjury that were punishable by fine, or imprisonment or both or transportation for a period not exceeding seven years. It had civil jurisdiction in all matters up to £20. The Court was abolished by 7 Vic. No. 8 (passed 27 June 1844 and taking effect 30 September 1844).

69 New Zealand Gazette and Wellington Spectator, 1 May 1844, 3, reporting on the Supreme Court session of 12 April 1844. 
Southern District before Edmund Storr Halswell, Judge of the County Court. It appears from the report that Chapman's refusal to allow unsworn evidence in McCarthy was not expected by those in court.

An editorial in the New Zealand Gazette and Wellington Spectator sheds doubt on whether such testimony was given, at least as regards Halswell's practice. As noted above, the editor had called for an ordinance to admit unsworn testimony precisely because of an alleged refusal by Halswell to allow such testimony. While no record actually survives of Halswell refusing to allow unsworn testimony, in April 1844, Halswell did refuse to allow a juror to take part in proceedings who had refused to take the oath from 'conscientious scruples'. Having admitted to the court he was not a Quaker, but 'a member of the connexion of Wesleyan Methodists', he was excused. Halswell is reported as saying that he would refer the matter to the Supreme Court..$^{70}$ On the other hand, Halswell was not above unconventional procedure. On a number of occasions he invited others to sit on the bench with him. In Te Kopo and E Pokai, both charged with theft, Halswell allowed Turingha Kuri the 'Chief of Kai warra warra', to sit on the bench with him and to give his opinion on the matter, ${ }^{71}$ while in $E$ Waho both Bishop Selwyn (the first Anglican Bishop of New Zealand) and Moturoa (a Chief from the Wellington area) were invited to sit with him. ${ }^{72}$ Similarly, by his own admission, in Pakewa 'several leading chiefs sat on the bench with me'. ${ }^{73}$

There is, in fact, little evidence of Māori being admitted as witnesses before the County Court without taking the oath. It may be that this happened before the Magistrate's Court, which was largely staffed by laypersons, but what records remain of County Court proceedings suggests that most Māori were sworn, either as Christians, or as believers in future punishment and reward. In Lockwood, for example, E. Hape told the court that:

I am a missionary; I was induced to become a missionary because I believed in God, and that Christ was God; I know it to be wicked to tell lies, and if I do not speak the whole truth I shall be punished when I die. ${ }^{74}$

$70 R v$ Thompson, 16 April 1844, County Court, Nelson, Halswell J, reported in The Nelson Examiner and New Zealand Chronicle, 20 April 1844, 3. There is no record of any referral of the matter to the Supreme Court. $71 R v$ Te Kopo and E Pokai, County Court, Wellington, Halswell J, 28 June 1842, reported in New Zealand Gazette and Wellington Spectator, 2 July 1842, 3.

$72 R v E$ Waho, 19 December 1843, County Court, Wellington, Halswell J, reported in New Zealand Gazette and Wellington Spectator, 30 December 1843, 2; Journals of William Cotton, ATL, vol. 6, qMS-0566, entry for 19 December 1843, 39; Louis Ward, Early Wellington (Wellington: Whitcombe and Tombs, 1928), 125.

73 Halswell to Lord Lyttleton, 18 June 1846, in Copies or Extracts of Correspondence between the Colonial Office and $\mathrm{Mr}$ Halswell, relating to the Discharge of his Duties whilst Protector of Aborigines in New Zealand, ed. Barry Baldwin (House of Commons, London, 1846), 9. While Halswell does not mention the case, by description it must be $R v$ Pakewa, Court of Quarter Sessions, Wellington, Halswell J (Chairman), 4 October 1841, reported in New Zealand Gazette and Wellington Spectator, 6 October 1841, 3; 9 October 1841, 3. $74 R$ v Lockwood, County Court, Wellington, Halswell J, 24 May 1842, reported in New Zealand Gazette and Wellington Spectator, 28 May 1842, 3. 
Similarly, in E Waho, charged with stealing clothing, three witnesses, all Māori, appeared for the defence: Pomare, William E. Tako and Maria. ${ }^{75}$ Pomare, who was described as 'Chief of the Chatham Islands' was examined by the court as to his belief in future rewards and punishments, while Maria described herself as a 'church of England missionary native'. William E. Tako (Wiremu Tako), the 'Chief of Kumu Toto', was also presumably sworn. ${ }^{76}$

Not only was the appearance of Māori as witnesses in trials reasonably common in the period, their failure to appear was commented on adversely on several occasions. In $R v$ Hastings, a key witness, a Māori woman named Hannah, failed to turn up when called as witness. Halswell noted that this was the third case in which a Māori witness had not turned up and that two other cases had failed for this problem. While the defendant, Te Ito, gave evidence, it was insufficient in Hannah's absence to obtain a conviction. The impression is that Hastings was fortunate. ${ }^{77}$ Similar comments were made by Halswell at the trial of Daniel Munroe. $^{78}$ Two Māori had informed the chief constable that they had received certain goods, found to be stolen, from Munroe in return for potatoes to eat. While two other witnesses were called, only the Māori witnesses could connect Munroe with the stolen goods. He was acquitted. Where possible, the courts would compel witnesses to appear. ${ }^{79}$ However, Munroe is an example of how, in a limited way, Māori evidence could on occasion make its way before the courts, even in the absence of the witnesses themselves. In that case, the two pākehā witnesses recounted the story that they had been told by the missing Māori witnesses as to how they had acquired the stolen goods. Inclusion of these accounts in the trial was possible because the rule against hearsay did not emerge until later in the century, in part as a reaction by the courts to statutory reforms to competency.

$75 R v E$ Waho (Wahu, Awaho), County Court, Wellington, Halswell J, 19 December 1843, reported in New Zealand Gazette and Wellington Spectator, 30 December 1843, 2-3. E. Waho was committed in the Police Magistrates Court on 30 November 1843: New Zealand Gazette and Wellington Spectator, 6 December 1843, 3. Despite the prosecution calling ten pākehā witnesses, the jury initially returned a verdict of 'not guilty'. However, on being re-instructed by the judge the jury finally returned a guilty verdict.

76 A change in name can indicate that a particular Māori individual had been baptised or otherwise accepted Christianity, although it is by no means an entirely reliable indicator. There were many other reasons why Māori might adopt English names, and many Christian Māori who did not. Lyndsay Head notes that 'after conversion Māori were normally called by their baptismal name, which was usually an English or biblical name, transliterated into Māori'. The example she gives is that of Wi (or William/Wiremu) Tako (Lyndsay Head, 'Land, Authority and the Forgetting of Being in Early Colonial Maori History' (PhD thesis, University of Canterbury, 2006), 29). It is likely that Tako was a Christian in this period, and he died a Catholic. For more on Tako, see his obituary, Evening Post, 10 November 1887, 2.

$77 R v$ Hastings, County Court, Halswell J, Wellington, 20 December 1843, reported in New Zealand Gazette and Wellington Spectator, 6 January 1844, 3.

$78 R v$ Daniel Munroe, County Court, Halswell J, Wellington, 20 September 1843, reported in New Zealand Gazette and Wellington Spectator, 27 September 1843, 3.

79 At the inquest into the death of Archibald Milne the coroner, John Fitzgerald, was forced to adjourn proceedings and obtain a warrant to force Awaho to appear as a witness. Milne, 27 December 1841, Coroner's Court, Wellington, FitzGerald (Coroner) with Halswell and White JPs, reported in New Zealand Gazette and Wellington Spectator, 29 December 1841, 2. 


\section{Local law reform: The Unsworn Testimony Ordinance 1843}

By the time the Colonial Evidence Act was passed, therefore, Māori had been giving evidence, at least before both the Land Claims Court and the regular courts, for over three years. The desirability, however, of further extending the ability of Māori to give unsworn testimony from the limited arena of the Land Claims Court to the general courts of the colony had been noted in a number of quarters. In July 1843, for example, the editor of the New Zealand Gazette and Wellington Spectator, commenting generally on the - as he saw it - fairly unimpressive legislative agenda of the Legislative Council, questioned why no ordinance had been passed to allow unsworn evidence? After all, it would be more immediately practicable than 'preparing enactments relating to "the rule in Shelley's Case" or "contingent remainders"'. He noted the necessity for such an ordinance as:

[w] ithin the last six months, His Honor the Judge of the County Court of Wellington, did reject a Native witness because it appeared on examination that he did not acknowledge a Supreme being; but we understand that in other parts of this island the English rule of Law has been intrenched [sic] upon and such evidence admitted. ${ }^{80}$

The editor specifically noted that there was no excuse for such an omission, as such a provision was specifically provided for in the Land Claims Ordinance. Undoubtedly ignorant of the origins of that provision, and of the disallowance of the New South Wales Aboriginal Evidence Act, he sheeted home the failure to enact a local unsworn testimony ordinance to the change in attorney-general since the drafting of the Land Claims Ordinance. ${ }^{81}$ In 1844 the editor of the Wellington Spectator returned to the matter and noted for the benefit of his readers that the imperial parliament had now enacted a measure to allow for pagan evidence to be admitted without oath, and that it was to be hoped that the governor and council would soon pass such a measure, as they understood that otherwise a gross crime might be committed in the presence of pagan Māori only, as it once could have been in England before Quakers. ${ }^{82}$

Almost immediately after the passing of the Colonial Evidence Act, Governor FitzRoy moved to enact a local measure, bringing the Unsworn Testimony bill

80 Editorial, New Zealand Gazette and Wellington Spectator, 26 July 1843, 3.

81 ibid. Francis Fisher, the first attorney-general, was appointed from Sydney as an interim measure, awaiting the arrival of William Swainson. Swainson was appointed attorney-general on 21 September 1841. 82 Editorial Note on the opening of a new session of the Supreme Court, New Zealand Gazette and Wellington Spectator, 1 May 1844, 3. 
before the Legislative Council. ${ }^{83}$ The imperial Act simply provided that the passing of any act or ordinance to make admissible in any Court of Justice the evidence of those who were 'destitute of the knowledge of God and of any religious Belief' would not be held null, void or invalid because thought repugnant. ${ }^{84}$ Based on these words, and ignoring the clear limitation to 'tribes of barbarous and uncivilized People', Brown thought they could extend the reach of the Ordinance to all who had not had the benefit of religious education, a suggestion with which Sir Robert FitzRoy, Governor of New Zealand, at least initially agreed. ${ }^{85}$ Brown, whose interpretations of the Act appear to have somewhat irritated William Swainson, the attorney-general (who noted that $\mathrm{Mr}$ Brown 'appears to have great confidence in this own judgment'), understood the Act to mean that if three or four persons whose opinion could not be trusted agreed on a thing that would 'establish a fact', and this could be so equally whether they were barbarian or white man who had not had the benefit of a religious education. Dr Martin agreed. That, however, was clearly beyond the licence of the imperial Act. The result was, therefore, as Brown pointed out, that the aborigines had the advantage of a while man in this regard. ${ }^{86}$

Mr Brown was correct in this regard. The Colonial Evidence Act was passed at a time when a range of reforms were being considered to the law of evidence. Throughout the nineteenth century generally, statutory reforms were introduced to widen the category of those who were competent, but such reforms were accompanied by the concurrent development by the courts of exclusionary rules of evidence. Reform took place in two waves: the first, 1828-54, was directed towards those who were incompetent because of defect of religious principle. ${ }^{87}$ In 1828, statutory reform allowed Quakers and Morovians to affirm while, in 1833, similar reforms were introduced for Separatists. ${ }^{88}$ Brougham also gave his famous speech on law reform in 1828. Among other reforms, he urged that the rules be relaxed to allow anyone who believed in a supreme being and future reward and punishment to affirm. ${ }^{89}$ The second wave, in which reform was directed towards those with a lack of religious belief, was between 1854 and $1869 .{ }^{90}$

While proposals for a general right to affirm were placed before the British parliament as early as 1838 , the broader matter of atheistic evidence took longer

83 Unsworn Testimony Ordinance, 7 Vic. No. 16 (1844).

84 Colonial Evidence Ordinance 6 Vic. c. 22 (1843) (Imp.), s. 1.

85 The Southern Cross, 13 July 1844, 3-4, reporting on the proceedings of the Legislative Council for Tuesday 9 July 1844.

86 ibid.

87 C.J.W. Allen, 'Bentham and the Abolition of Incompetency from Defect of Religious Principle', The Journal of Legal History 16 (1995): 172, 173.

889 George IV c. 32; 3 \& 4 William IV c. 82.

89 Henry Brougham, A Speech on the Present State of the Law of the Country; delivered in the House of Commons, on Thursday, 7 Feb., 1828, second edition (London: Henry Colburn, 1828), 4; Allen, 173.

90 Allen, 173. 
to be addressed, and those with no religious belief were not finally permitted to give evidence until 1869. ${ }^{91}$ Arguments against admitting evidence from unbelievers were diverse but, according to Allen, the most common opposition was based on a belief that to allow such evidence would be 'to loosen the bonds of society'. Religion was 'fundamental to morality' and even a key component of being a good citizen. ${ }^{92}$ It was, in short, a component of the civilised society.

A second matter of contention before the Legislative Council was the matter of penalty for falsehood. Dr Martin was concerned that, as Māori would be subject to the same penalties as Europeans for swearing falsely, this might lead jurors to lend the same credit to their testimony as to evidence given on oath. Further, punishment 'would not make [Māori] moral characters; that they could not be compared with the Quakers, who gave their evidence on affirmation, it was not right to inflict the same punishment on the savage as the civilized Quaker' ${ }^{93}$ To the contrary, Charles Clifford thought Dr Samuel Martin's arguments to be reasons in favour of the bill: 'civilized men had a fear of society before their eyes, which could punish them in many ways; the savage had no such fear'. The governor agreed. Children found telling a falsehood could be corrected without regard to their weak intellect, and the uninformed savage was but a child of larger growth, but with more mature passions'. In any case, 'no definite punishment was mentioned'; it was to be left to the judge to determine the enormity of the offence if it could be proven that evidence had been given falsely and wilfully. ${ }^{94}$ This was the more controversial matter. Allowing unsworn evidence by Māori excited no discernible opposition, but the matter of the ability of the 'uncivilized Māori' to recognise and attach importance to truth, and whether they should be punished in consequence, was doubted by several members of the council. Dr Martin insisted that the bill be altered and, while he might have argued out the matter, in the end the attorney-general's bill carried the day. All were in favour. ${ }^{95}$ And with that New Zealand became the first colony to enact legislation to allow unsworn testimony before the courts.

\footnotetext{
91 Evidence Further Amendment Act 1869 (UK).

92 Allen, 179-81.

93 The Southern Cross, 13 July 1844, 3-4, reporting on the proceedings of the Legislative Council for Tuesday 9 July 1844.

94 ibid.

95 There was a third matter of contention, quickly dealt with. Was it possible to admit the evidence of natives of all countries, or just of those countries 'adjoining', as stated in the preamble? Based on the words of the preamble, this matter was settled in accordance with Swainson's interpretation that the scope be confined to those from adjoining colonies: ibid.
} 


\section{Conclusion}

After the passing of the Ordinance, Māori continued to give evidence before all courts, but without the need to demonstrate a belief in future reward and punishment. ${ }^{96}$ Unlike in New South Wales, where, despite the passing of the Colonial Evidence Act, Indigenous Australians remained unable to give evidence until 1876, the passage of the Unsworn Testimony Ordinance in New Zealand was not only without controversy, but welcomed in many quarters. This was not just because Māori had already been giving evidence before the Land Claims Court, but because of their place in settler society - many lived in towns, took part in commerce, were Christians and were literate. It would have been difficult to conduct day-to-day legal affairs in Auckland, Nelson or Wellington without involving Māori and impossible, in many cases, to secure conviction. In particular, of course, the very reason they could give evidence before the Land Claims Court was because without that evidence settlement simply could not have proceeded. The high level of interaction between Māori and pākehā in settlements like Wellington, so soon after Britain's acquisition of the colony, set New Zealand apart from the Australian colonies. The particular history of unsworn testimony in New Zealand serves to remind us that, beneath the broad legal frameworks of empire, the local micro-politics and the particular situation of the indigenous inhabitants led to very different and diverse outcomes.

\section{Acknowledgments}

My thanks to Megan Simpson, Damen Ward, Ned Fletcher, Brent Parker and Sam Ritchie. The usual disclaimer applies. Some of the materials in this article were recovered by the New Zealand Lost Cases Project. This project was funded by the New Zealand Law Foundation, and recovered Supreme Court cases, and contextual materials relating to those cases, from 1841-69. Source materials, cases and other general information are available at http://www.victoria.ac.nz/ law/nzlostcases/

96 Before the Supreme Court see $R v$ William Johnson, 1 March 1847, Martin CJ, reported in New Zealander, 6 March 1847, 3; Before the Resident Magistrate's Court (which replaced County Courts in 1846) see $R v$ Honeri, Rews and Ngatauhira, 26 September 1949, Beckham JP, reported in Daily Southern Cross, 30 September 1859, 3. 